\title{
Applications of information and communication technologies in the operations of industrial enterprises and the conception of economic security controlling
}

\author{
Victor Kashtanov ${ }^{1, *}$, and Valerii Kalinin ${ }^{1}$ \\ ${ }^{1}$ Institute of Lifelong Education, 109542, 86/1 Ryazan ave., Moscow, Russia \\ ${ }^{2}$ Market Economy Institute of the Russian Academy of Sciences, 117418, 47 Nakhimovskij ave., \\ Moscow, Russia
}

\begin{abstract}
The research paper is devoted to the applied and the new information and communication technologies in the activity of industrial enterprises and also to ensuring the security of information as a result of the implementation of such a modern tool as controlling. The article deals with controlling procedures in relation to network, information, economic, and digital security of an industrial enterprise. The characteristics of each type of industrial enterprise safety, including cybersecurity, are given. The statistical data on availability in the organizations of the Russian Federation are analyzed: personal computers; servers; local area networks; e-mail; global information networks, of which: Internet; organizations, possessed web-site on the Internet. Data of Information and Communication Technologies in Organizations are presented by Economic Activity. Based on the studied fundamental and scientific works, the authors proposed the concept of controlling the economic security of an industrial enterprise using modern information and communication technologies. The concept of controlling economic security includes the use of information and communication technologies in the activities of industrial companies and contains the following elements: objectives; structure; procedures; tools and results analysis. Conclusions are made using a systematic approach to the study. The results of the research can be used to develop controlling programs and to verify the economic safety of industrial enterprises. In the future, the authors consider the possibility of creating their own database for controlling the economic security of hightech companies of the Russian Federation.
\end{abstract}

\section{Introduction}

The most important factor of stabilizing the economy, as well as the main condition for maintaining a high level of national security of the country as a whole, as well as individual economic entities (industrial enterprises) in particular, is the use of modern (advanced),

\footnotetext{
* Corresponding author: psvpon@mail.ru
} 
breakthrough information and communication technologies. In order to create favorable conditions for the development of industrial enterprises in the Russian Federation, it is necessary to introduce new and maintain at the proper level already existing information and communication technologies, methods of controlling the economic security of industrial enterprises. The relevance of the research topic is related to the development of the digital economy in the Russian Federation, the emergence of new technologies in the activity of economically significant subjects, therefore to the role of ensuring economic security. The aim of the research is to present a new concept of economic security of an industrial enterprise operating in the digital economy. The object of research is industrial enterprises operating in the modern digital economy and using information and communication technologies. The subject of the study is management relations arising in the process of controlling ICT and ensuring the economic security of an industrial enterprise.

\section{Materials and methods}

General scientific methods and methods of research were used in the work. The basis for this work was the fundamental and scientific works of foreign scientists in the field of three knowledge: controlling, economic security and the use of information and communication technologies in the operations of industrial companies. The research topic is popular among scientists all over the world, among the authors dealing with this problem should be distinguished the following: A. Guliyeva, I. Britchenko, U. Rzayeva [1]; A. Ohotina, O. Lavrinenko, S. Ignatjeva, J. Lonska [2]; A. Smirnov, O. Lavrinenko, V. Tumalavicius [3]; B.Y. Bagde, B.S. Umre [4]; E. Karanina, E. Sapozhnikova, O. Ryazanova, S. Grin [5]; E. Karanina, K. Kartavyh [6]; E. Kazantseva, G. Chistyakova [7]; I. El-Anis [8]; J. Alwang, S. Sabry, K. Shideed, A. Swelam, H. Halila [9]; J. Neubauer, J. Odehnal [10]; J.D. Wilson [11]; J.E. Mutchler, Y. Li, P. Xu [12]; M. Vlasova, O. Stepchenkova, I. Lobanova, A. Smirnova [13]; M.Van Holstein, M.I. Froböse, J. O'Shea, E. Aarts, R. Cools [14]; T. Takatani, K. Fujita, K. Tanaka, T. Funatomi, Y. Mukaigawa [15]; T. Tuleneva [16]; Y. Yu, P. Luh [17] and others. Among Russian authors dealing with the problems of application, adaptation of information and communication technologies (hereinafter referred to as "ICT") in the operaions of industrial enterprises, it is necessary to single out: S.V. Ponomareva, N.A. Merzliakova [18]; I.V. Zheleznova [19] and others.

\section{Results and Discussion}

Discussion on the need to use information and communication technologies in the activities of industrial companies and their safety is not one year. Almost every company that operates in the Russian Federation, especially if it is a question of industrial companies, certainly has an ICT in its arsenal. Therefore, the task of the company's special services is to ensure the safest entry, exit from the systems, check the current technologies and so on. In that regard, Table 1 presents a description of the types of security of an industrial enterprise and the procedure for applying controlling to them.

Table 1. Characteristics of types of industrial enterprise security and application of controlling to them.

\begin{tabular}{|l|l|l|l|}
\hline № & $\begin{array}{c}\text { Types of security in an } \\
\text { industrial enterprise }\end{array}$ & $\begin{array}{c}\text { Characteristics of the types of } \\
\text { industrial enterprise safety }\end{array}$ & $\begin{array}{c}\text { Application of controlling to } \\
\text { types of security in an industrial } \\
\text { enterprise }\end{array}$ \\
\hline 1 & Network Security & $\begin{array}{l}\text { Secure access for employees } \\
\text { and employees to network }\end{array}$ & $\begin{array}{l}\text { Controlling reveals the problems } \\
\text { of building an integrated }\end{array}$ \\
\hline
\end{tabular}




\begin{tabular}{|l|l|l|l|}
\hline & & resources & $\begin{array}{l}\text { protection system at the network } \\
\text { and transport levels of an } \\
\text { industrial enterprise. }\end{array}$ \\
\hline 2 & Information Security & $\begin{array}{l}\text { Preservation of information } \\
\text { resources and verification of } \\
\text { the protection of legal rights }\end{array}$ & $\begin{array}{l}\text { Controlling information security } \\
\text { provides control of information } \\
\text { resources of an industrial } \\
\text { enterprise. }\end{array}$ \\
\hline 3 & Cybersecurity & $\begin{array}{l}\text { Implementation of measures } \\
\text { to protect systems, networks } \\
\text { and software applications } \\
\text { from digital attacks }\end{array}$ & $\begin{array}{l}\text { Controlling for cybersecurity } \\
\text { involves identifying issues in } \\
\text { cybersecurity tools, tools, } \\
\text { strategies, principles, and } \\
\text { networks. }\end{array}$ \\
\hline 4 & Economic security & $\begin{array}{l}\text { The combination of } \\
\text { conditions, production, } \\
\text { technological, economic, } \\
\text { legal factors that ensure the } \\
\text { sustainable development of an } \\
\text { industrial enterprise }\end{array}$ & $\begin{array}{l}\text { Controlling the economic } \\
\text { security of an industrial } \\
\text { enterprise includes subsystems } \\
\text { for analysis, planning, } \\
\text { management, accounting, } \\
\text { control, and others. }\end{array}$ \\
\hline 5 & Digital Security & $\begin{array}{l}\text { Measures to protect the } \\
\text { confidentiality, integrity and } \\
\text { accessibility of information } \\
\text { from virus attacks and } \\
\text { unauthorized access to digital } \\
\text { assets of an industrial } \\
\text { enterprise }\end{array}$ & $\begin{array}{l}\text { Controlling digital security } \\
\text { ensures the security of digital } \\
\text { assets of an industrial enterprise. }\end{array}$ \\
\hline
\end{tabular}

From Table 1 it follows that in Russian industrial enterprises all the main types of safety are applied, but especially topical authors consider information, economic and digital security. Table 2 presents statistical data on the information and communication technologies used in the activities of enterprises of the Russian Federation.

Table 2. Use of Information and Communication Technologies in Organizations (percent of total number of observed organizations).

\begin{tabular}{|l|l|l|l|}
\hline Organizations used: & 2014 & 2015 & 2016 \\
\hline personal computers & 93,8 & 92,3 & 92,4 \\
\hline Servers & 26,6 & 47,7 & 50,8 \\
\hline local area networks & 67,2 & 63,5 & 62,3 \\
\hline e-mail & 84,2 & 84,0 & 87,6 \\
\hline global information networks & 89,8 & 89,0 & 89,6 \\
\hline $\begin{array}{l}\text { Organizations, possessed web- } \\
\text { site on the Internet }\end{array}$ & 40,3 & 42,6 & 45,9 \\
\hline
\end{tabular}

From the table 2 «Organizations used» in 2016: $92.4 \%$ - personal computers; $50.8 \%$ servers; $62.3 \%$ - local area networks; $87.6 \%$ - e-mail; $89.6 \%$ - global information networks, of which: $88.7 \%$ - Internet; $45,9 \%$ - Organizations, possessed web-site on the Internet. In tabl.3 data are presented using of Information and Communication Technologies in Organizations by Economic Activity.

From the information presented in Table 3 it follows that the leading positions in the following organizations as of December 31, 2016: Manufacturing - 91.3\%; Wholesale and retail trade; repair of motor vehicles, motorcycles and personal and household goods 91.6\%; Higher vocational education - 93,9\%. Organizations, possessed website (s) on the Internet: Higher vocational education - 80.9\%; Health and social work - 64.9\%; Financial intermediation $-64,7 \%$; Manufacturing $-62.3 \%$. As a result of the analysis of statistical data and studying the fundamental foreign, domestic sources, the authors propose the 
concept of controlling the economic security of industrial enterprises using modern information and communication technologies. The concept of controlling economic security, including the use of information and communication technologies in the activities of industrial companies, contains the following elements: objectives; structure; procedures; tools and analysis of results (Fig. 1).

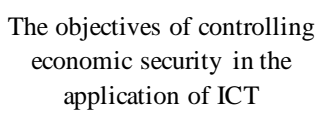

The structure of controlling economic security in the application of ICT

Procedures for controlling economic security in the application of ICT

Instruments of controlling economic security in the application of ICT

Analysis of control results and preparation of recommendations
1. Control of economic results in the application of new ICT.

2. Identification of inefficient information and communication technologies

3.Development of relevant management decisions.

1.Controlling of functional structures.

2. Controlling schemes of organizational relations.

3. Controlling the organizational structure.

4. Controlling the professionalism of employees in the application of ICT.

5. Controlling the economic security of such subsystems as analysis, planning, management, accounting, control

1.Controlling of communications.

2. Controlling business process diagrams.

3. Detection of digital attacks.

4. Insurance against risks.

5. Verification of information support.

6. Inspection of fixed assets of industrial companies.

7. Controlling communication networks.

8. Controlling the workflow.

9. Controlling security work on the Internet.

1. Strategic control of the economic security of ICT.

2. Operational control of the economic security of ICT.

1. Analysis of identified problems as a result of controlling. 2. Development of recommendations on the elimination of problems and the implementation of management decisions. 3 . Acquisition of software products and special equipment that provides economic security in the application of ICT.

Fig. 1. The concept of controlling the economic security of industrial enterprises with the use of modern information and communication technologies.

The sphere of application of the concept of controlling economic security with the use of information and communication technologies is high-tech companies and large economic entities, important for the Russian economy, are entrepreneurs. 
Table 3. Use of Information and Communication Technologies in Organizations by Economic Activity (percent of total number of surveyed organizations of the relevant activity).

\begin{tabular}{|l|c|c|c|c|c|c|}
\hline \multirow{2}{*}{ Organizations by Economic Activity } & \multicolumn{3}{|c|}{$\begin{array}{c}\text { Organizations that used } \\
\text { broadband access to the }\end{array}$} & \multicolumn{3}{c|}{$\begin{array}{c}\text { Organizations, } \\
\text { possessed website(s) } \\
\text { on the Internet }\end{array}$} \\
\cline { 2 - 8 } & 2014 & 2015 & 2016 & 2014 & 2015 & 2016 \\
\hline Mining and quarrying & 88,7 & 86,6 & 88,8 & 34,5 & 37,2 & 41,0 \\
\hline Manufacturing & 90,9 & 90,2 & 91,3 & 55,9 & 57,5 & 62,3 \\
\hline Electricity, gas and water supply & 78,8 & 77,6 & 80,1 & 34,2 & 38,6 & 41,8 \\
\hline Construction & 85,3 & 84,3 & 85,0 & 37,1 & 40,1 & 41,0 \\
\hline $\begin{array}{l}\text { Wholesale and retail trade; repair of motor } \\
\text { vehicles, motorcycles and personal and } \\
\text { household goods }\end{array}$ & 88,3 & 87,6 & 91,6 & 48,5 & 53,3 & 53,5 \\
\hline Hotels and restaurants & & & & & & \\
\hline Transport and communications & 78,3 & 77,7 & 75,3 & 38,2 & 42,2 & 44,4 \\
\hline Financial intermediation & 79,0 & 77,0 & 76,3 & 35,5 & 36,9 & 37,7 \\
\hline Real estate, renting and business activities & 91,9 & 89,3 & 89,3 & 60,7 & 61,6 & 64,7 \\
\hline $\begin{array}{l}\text { Public administration and defense, } \\
\text { compulsory social security }\end{array}$ & 82,3 & 68,7 & 69,9 & 29,9 & 29,7 & 31,7 \\
\hline Higher vocational education & 80,7 & 85,0 & 39,3 & 40,9 & 45,2 \\
\hline Health and social work & 94,6 & 92,5 & 93,9 & 77,2 & 78,7 & 80,9 \\
\hline Recreation, cultural and sport activities & 89,1 & 88,4 & 89,9 & 52,7 & 59,0 & 64,9 \\
\hline Other activities & 68,1 & 69,2 & 71,7 & 27,7 & 32,0 & 37,3 \\
\hline
\end{tabular}

\section{Conclusion}

In the course of the research, the state and availability of information and communication technologies in the activities of industrial enterprises of the Russian Federation were comprehensively analyzed. The presented statistical data and the personal experience of the authors of the study made it possible to present the concept of controlling the economic security of industrial enterprises using modern information and communication technologies, which contains the following elements: goals; structure; procedures; tools and results analysis.

\section{References}

1. A. Guliyeva, I. Britchenko, U. Rzayeva, Journal of Security and Sustainability Issues, 7, 4, pp. 707-717 (2018)

2. A. Ohotina, O. Lavrinenko, S. Ignatjeva, J. Lonska, Journal of Security and Sustainability Issues, 7, 3, pp. 427-438 (2018)

3. A. Smirnov, O. Lavrinenko, V. Tumalavicius, Journal of Security and Sustainability Issues, 7, 4, pp. 817-829 (2018)

4. B. Y. Bagde, B. S. Umre, Security constrained economic dispatch 2017 International Conference on Energy, Communication, Data Analytics and Soft Computing, ICECDS 2017, 4, pp. 3458-3462 (2018)

5. E. Karanina, E. Sapozhnikova, O. Ryazanova, S. Grin, Espacios, 39, 28, p. 11 (2018)

6. E. Karanina, K. Kartavyh, MATEC Web of Conferences, 170 (2018)

7. E. Kazantseva, G. Chistyakova, E3S Web of Conferences, 41 (2018)

8. I. El-Anis, Journal of Developing Societies (2018) 
9. J. Alwang, S. Sabry, K. Shideed, A. Swelam, H. Halila, Food Security, 10, 3, pp. 589601 (2018)

10. J. Neubauer, J. Odehnal, AIP Conference Proceedings, 1978 (2018)

11. J. D. Wilson, East Asia, 20, pp. 1-20 (2018)

12. J. E. Mutchler, Y. Li, P. Xu, Journal of Aging and Social Policy, 15, pp. 1-15 (2018)

13. M. Vlasova, O. Stepchenkova, I. Lobanova, A. Smirnova, MATEC Web of Conferences, 170 (2018)

14. M. Van Holstein, M.I. Froböse, J. O'Shea, E. Aarts, R. Cools, Scientific Reports, 8 (2018).

15. T. Takatani, K. Fujita, K. Tanaka, T. Funatomi, Y. Mukaigawa, IPSJ Transactions on Computer Vision and Applications, 10 (2018).

16. T. Tuleneva, E3S Web of Conferences, 41, (2018)

17. Y. Yu, P. Luh, International Journal of Electrical Power and Energy Systems, 98, pp. 269-278 (2018)

18. S. V. Ponomareva, N.A. Merzliakova, Journal of Physics: Conf. Series, 1015, 032093. DOI:10.1088/1742-6596/1015/3/032093 (2018)

19. S. V. Ponomareva, I. V. Zheleznova, Journal of Physics: Conf. Series, 1015, 032106. DOI: $10.1088 / 1742-6596 / 1015 / 3 / 032106$ (2018) 